\title{
Reading the self in Persian prose and poetry
}

Let us start with a thought experiment. Five hundred years from now, when I am long dead and forgotten, a reader comes across this essay and other writings I have published. How would such a reader understand the referent to be associated with my use of the word 'I' in such documents? Would she be justified in claiming to know me as a human subject based on having read words that invoke the grammatical first-person pronoun? I suspect not, despite the sense of intimacy my usage intends. But the lack of direct knowledge would be due neither to an insincere use of the pronoun on my part nor to a fault in her reading. The complication is that the 'I' invoked in my academic publications is a genre-bound evocation. In using it, I am taking up a posture allowed by conventions of academic writing as it is practised today. This 'I' has a tempered relationship with my full human subjectivity. It cannot bear the burdens of my other uses of the same pronoun in conventional speech, such as when I talk to a family member, or address a shopkeeper, or struggle to make myself understood by someone who does not know English. The word 'I' is a quasi-homonym that can refer to variant, although often interconnected, parts of my existence as a being in the world.

I spend my time trying to understand and interpret people who lived, and wrote, hundreds of years ago. The thought experiment I begin with is helpful for me to undertake such work. The uses of the first-person pronoun I come across in evidence from the past available to me are, simultaneously, conditions of possibility for my work and barriers that mask my access to the people who composed the texts. A writer's use of 'I' allows me to locate a piece of evidence in spatiotemporal terms relative to my own understandings. It brings to mind a living body like my own, the shared corporeal form warranting interpretability across time and space. But the commonsensical affinity is an illusion because of the intermediacy of matters such as genre, posture, rhetorical positioning, and bias with respect to the immediate circumstances in which the original text was produced. On the side of production, these factors stand between the written 'I' and the person who produced it. On my side, current intellectual and sociohisotircal limitations condition me to understand the materials in ways far removed from the originating context.

The problem of interpreting an 'I' that comes to us from social contexts long dead provides a venue to think productively about interoperability between individuality and dividuality. In one sense, the first-person pronoun is the most concrete marker of individuality, the grammatical assertion of one person distinguished from others. Yet, as indicated above, invocation of the pronoun necessarily signifies only a part of the putative individual, subject to rules of linguistic genre and social situation. In 
this sense, the 'I' is a marker of dividuality, conditioned by the fact that the human subject is socially constituted by all that surrounds her. As seen in the written ' $\mathrm{I}$ ', individuality and dividuality are the proverbial two faces of the same coin.

I propose to utilise the individuality-dividuality distinction as a tool for exploring literature that contains extensive use of the first-person voice. My specific quarry consists of materials in Persian. I believe my conceptualisation of the problem extends to other contexts and literary traditions, but I leave it to specialists in those fields to adjudicate its usefulness. As discussed extensively by now, the academic debate regarding in/dividuality has its roots in ethnographic work invested in categorising cultures presumed to have differing ways of constituting human subjectivity. The ethnocentrism that characterised the initial formulations has been criticised through showing that cultures that were characterised initially as individualistic or dividualistic could, as easily, be described as belonging to the opposite category (e.g. Smith 2012). What, then, is the benefit of retaining the distinction as a part of analytical approaches to human cultural situations? For me, the in/dividuality distinction does have value, not as a way to categorise cultures but as a lens that can help us parse certain types of materials and situations. Analysing invocations of the first-person voice seems to me to be an especially significant instance in this regard.

\section{A resurrection of poetry}

I wish to draw out the relationship between the first-person voice and in/dividuality by concentrating on a single, lengthy work composed in India in the 17th century CE that is exemplary for the problematic at hand. The work is an artful description of the lives and work of individuals described as practitioners of the art of composing poetry in Persian over a period of about seven centuries (c. 950-1650 CE). The work's framing comes from a single compiler, although it introduces us to the voices of thousands of authors. I will first provide a brief description of the work and then analyse the way the first-person voice figures in it.

Taqī al-Dīn Muḥammad Awḥadī Daqqāqī Balyānī's 'Arafāt al-'āshiqīn va 'arașāt al- 'ārifīn (The Resurrection Ground of Lovers and the Courtyards of Knowers) is one of the most extensive biographical dictionaries of Persian poets ever composed (Gulchīn Ma'ānī 1985, 2:3-21). Initiated during the period 1613 - 1615 CE in Agra, India, it was added to by the author until his death circa 1640. It contains entries on more than 3500 poets, distributed over nearly seven centuries and throughout the Persian-writing sphere spread over Iran and Central and South Asia. Published for the first time in 2009 and 2010 in seven- and eight-volume 
modern editions on the basis of five manuscripts, this work has received minimal scholarly attention besides being cited occasionally as a source of information for one or another poet. Since the publication of the printed editions, the work has begun to be mined to comment on literary and social patterns relevant for the early modern period in Iran and India (e.g. Āl-i Dāvūd 2008; 1996). The work is an exceedingly long unified narrative in which the author's first-person voice interpolates his reportage on poets, dead and alive. The work's narrative is prefaced by an account of the author's birth and early years in Iran, his passage to India, and subsequent travels in northern and southwestern parts of the subcontinent. But a far greater use of the first-person pronoun in his work occurs in citations of poetry attributed to the thousands of poets that are his subject. The work's monumentality can be gauged from the fact that the printed versions run to nearly five thousand pages.

Balyānī's valuation of poetry as speech worthy of extensive archival attention derives from his view of the relationship between the cosmos and the human ability to vocalise. This is encapsulated in the following cryptic description, part of the introduction:

It is written and remembered that the world is a shell that contains the pearl that is Adam,
and Adam is the shell that contains the pearl that is the world. This is so because the shell sur-
rounding the pearl that is the world is speech, and speech is the pearl that lies within Adam's
shell. Then it follows that every pearl in the realm of speech must be like a shell and every shell
in the realm of speech must be like a pearl. Indeed, God has a treasure under his throne, which
is touched by prophets and flows on the tongues of poets.
(Balyāni 2010, 1:8)

This statement needs unpacking in some detail to understand Balyānī's conceit regarding the status of poetry and poets. The first sentence evokes equivalence between the macrocosm and the microcosm, the world and the human being. A commonly held view in Balyānì's context, the effect of this understanding is that the human person is thought to encompass all that can come to pass in creation. The second sentence begins by locating the source of the equivalence in speech: the 'shell surrounding the pearl that is the world' is a reference to the divine command 'be', as described in the Quran and its predecessor texts. God's speech in the form of this 'be' created the macrocosm and hence, in a fashion, contains it. The sentence then continues to the effect that the foremost quality of the microcosm (Adam) is that it possesses speech. Overall, then, we are presented with the picture that God's speech initiated the creation of the world and the world is consummated by the human being capable of speech. Human capacity for language is a creative force that echoes the initial divine 'be' that gave rise to the world.

In the third sentence, we move to speech itself, which is represented as bifurcated into 'shell' and 'pearl'. Every bit of speech has an outward form and an inner 
precious quality, the two aspects being distinct but conjoined. A 'pearl' of speech is a specimen beautiful on the outside; but this pearl is itself a shell that contains something valuable inside of it, namely its pearl-like meaning. The pearl/shell, inside/outside binary can get ever deeper indefinitely in that all external forms of speech give rise to meanings, which can then be expressed in more speech, which has meanings, and so on.

The conclusion of this understanding comes in the last sentence, which identifies prophets and poets as those human beings who have the most intimate connection to God's treasure, meaning speech. Prophets 'touch' this treasure, since God doles it out to them in the form of scriptures that they then convey to other human beings. And the treasure flows endlessly on the tongues of poets in the form of the precious speech they create and share with others. God's initial 'be' creates the world, and poets recreate it in the continuing flow of their words. Poetic speech also marks the human being's intermediary status between God and the world. Balyānī's description gives poetry a generative function in the working of the world, and poets are a special class of humanity: the lovers and knowers mentioned in Balyānī's title (The Resurrection Ground of Lovers and the Courtyards of Knowers). They also actuate an eternal, quasi-divine function pertaining to the cosmos. Poetic voice and capacity are understood as constants in the world even as poets come and go, live and die. Poets' corporeal presences are vehicles for the continual generation of poetry as a cosmologically essential presence.

Although biographical dictionaries dedicated to poets and others had been a staple of Persian literature long before Balyānī's lifetime (see Gulchīn Ma'ānī 1985), his work contains a unique organisation tied to his overall attitude to language. He creates a multi-level order that criss-crosses between language, space, and time. Balyānī asks the reader to imagine time as a vast plain akin to the plain of 'Arafat in Mecca that figures prominently in the annual rite of the hajj. People who go to the pilgrimage are required to stand in this plain for several hours during one day as a preview for the resurrection that is expected to happen at the end of time. In Islamic eschatology, God is expected to reconstitute all humans to be present at such a plain once the world has been dissolved. Balyānī's invitation to imagine time as a resurrection plain self-consciously mimics the divine function, except that his purview is limited to the segment of humanity that consists of Persian poets. As in the ultimate resurrection, Balyānī's resurrection collapses the normative sequencing of time and allows people from all periods to be present simultaneously in a single narrativised place.

The resurrection ground - a representation of embodied time consisting of poets' lives - is then imagined as a space split into twenty-eight courtyards that correspond to the letters of the Arabic alphabet. In this process, time that had first become space is now divided into the building blocks of language. Each courtyard/ 
letter is then divided into three enclosures that contain poets divided between 'the ancients' (mutaqaddimin), the 'middle period ones' (mutavassitīn), and the 'lately arrived ones' (muta'akhkhirin). Poets are placed in the enclosures within the courtyards on the plain according to where their poetic pen names (takhalluș) occur in the alphabetical order. The division into enclosures brings a temporal structure back into the scheme, although the categorisation is now subordinate to the rule of language embodied in the alphabet. Time is first eliminated and then re-established as a sub-category within the linguistic abstraction that is the alphabet. ${ }^{1}$

Balyānī's work sticks to the proposed order throughout and contains reports, of widely varying lengths, on about 3500 poets, with brief comments on their lives together with samples of poetry and comments on their literary value. Islamic eschatological narratives emphasise the fundamentally individual nature of the event of the final resurrection. On that day, human beings are supposed to answer for their deeds without aid from anyone else. Balyānī's poetic resurrection effects this as well in that the alphabetical categorisation eliminates calendrical or genealogical time sequencing. Moreover, the organisational scheme dispenses with geography, ideological belonging, and social hierarchy such as the differences between king and pauper or men and women. The catalogue of poets also includes some Hindus, and Balyānī has special praise for satirists, antinomians, and characters described as religiously deviant, whose verses mock those invested in normative Islamic authority. The sum of these characteristics is a narrative that contains an alphabetical resurrection of individuals on a homogenising plain, committed to giving exemplary language primacy over other forms of categorisation.

An overall assessment of Balyānī's work reveals him as a person with a remarkably prodigious memory, a talent for taxonomy, and firm belief in his own authority to judge the worth of poetic expression in Persian. We might consider his presentation an instance of what is today called 'big data', whose efficacy is predicated on processing voluminous information combined with a deliberate loss of particularising details. He delights in appreciating both the exemplary and the unusual when it comes to versified expression in Persian. He sees poets contemporary to him as belonging to a transhistorical class that together carries the weighty burden put on poetry as an aspect of the cosmos. ${ }^{2}$

1 The conceptualisation of some of Balyānī's other works also indicates a concern with alphabetisation and imagery associated with the Ka 'ba. For example, his Surma-yi Sulaymanī (Solomon's Collyrium) (Balyānī 1985) is an alphabetical dictionary of difficult vocabulary encountered in Persian. His long poetic works include Ka'ba-yi dīdār (Ka'ba of Sight) and Ka'bat al-haramayn (Ka'ba of the two sanctuaries) (Balyānī 2010, lxi).

2 Although very extensive, Balyānī's work also has clear geographical biases in terms of the way the Persian poetic tradition is covered. Particularly for the contemporary period, his greatest 


\section{A tale of two voices}

With this overall picture in mind, let us now move to consider the question of in/ dividuality in Balyānī's work. My point of concentration is the first-person voice, for which the work has two contrasting pivots. It deploys an autobiographical narrative in prose that, first, introduces the author to the reader, and is then used continually throughout the rest of the work to indicate Balyānīs opinions. This voice occurs also in accounts of the author's personal encounters with those he had met and decided to include in his work. This usage bears comparison with my own use of the word 'I' in academic work, together with its attendant limitations. That is, it conveys an aspect of the authorial person as this could be articulated in Persian prose in a work that is a mixture of memoir and poetic prosopography, executed in an especially innovative form. In this paper, I refer to this usage as the 'prosaic self'.

The clear majority of Balyānīs text consists of citations of Persian poetry, distributed into more than 3500 entries pertaining to poets identified by name. Taken together, the massive poetic corpus presented in the work is replete with the first-person voice, although this usage is very substantially different from the autobiographical self. This is the universal poetic voice, bound to a set of well-known literary tropes, which all poets adopt to create linguistic products understandable to audiences initiated into the discourse. This utilisation - which I refer to as the 'poetic self' - can appear, on the surface, to be deeply personal. However, the poetic self refers to the universal human subject, and poetic speech encapsulates a persona available for adoption by those who wish to compose this type of poetry. The poetic self enables claims of linguistic virtuosity based on the ability to inhabit the imaginary universe presumed to surround the poet. Although exceedingly 'self-centred', the poetic self is a highly generalised subject position fundamentally distinct from poets as complex living persons. However, as I will discuss, the poetic voice is not impersonal; it is a tropological vehicle for the expression of personality. ${ }^{3}$

How are the prosaic and poetic selves encountered in Balyānī's work individualistic and dividualistic? This question constitutes the frame for my assertion

\footnotetext{
praise is reserved for people of his own type, namely Iranians who had made names for themselves in Iranian or Indian courts. A complete evaluation of Balyānī’s view of the poetic tradition would be a massive undertaking that has yet to happen.

3 For an excellent discussion of the construction of the poetic persona in Persian as this pertains to the early modern period see Losensky 1998. The point about the literary self as a generic convention is not exclusive to Persian and has been discussed in the context of many literary traditions.
} 
that debates over in/dividualism can help us engage productively with complex literary products. The analytical distinction between individuality and dividuality helps us to see the contrast between the two types of selves critical to understanding not just Balyānī's work but the overall way in which pre-modern Persian literature relates to the societies in which it was produced. ${ }^{4}$

I would like to preface my presentation of the work's details by summarising a set of conceptual conclusions. Stating these in advance should help to clarify my choices of examples. I contend that both the prosaic and the poetic selves are equally individualistic and dividualistic, but in contrasting ways. The prosaic self, the grammatical subject of autobiographical comments in Balyānī's work, is individualistic through outside designation. This self describes its uniqueness through matters such as the date and conditions of the author's birth and his undergoing particular experiences in circumstances that are described through reference to external historical events. The prosaic self is substantiated as a unique entity also through references to appreciation by others, such as when kings and connoisseurs of poetry and religious thought are reported to remark on his extraordinary gifts.

The prosaic self is dividualistic through subordination to authoritative social and discursive patterns. Balyānī's work is rooted in the autobiographical voice's appeals to normativity as this is produced through external social structures. Balyānī defines himself for the reader by emphasising an exalted genealogy and the fact that he had received poetic inspiration directly from God. In prose, he is keen to portray himself as someone who is a part of existing hierarchies, a cog in the wheels of time and society rather than someone who stands apart through exception. The individualistic and dividualistic sides of the prosaic self both portray the author as rooted in social settings. As an individual, the prosaic self is constituted through the appreciation of others, while as a dividual, it is marked by adherence to norms and values of the societal settings within which it is ensconced.

The poetic self is also both individualistic and dividualistic, although on different grounds. Its individualism has an assertive voice that speaks often in the first person and insists on its difference from the listener and the world at large.

\footnotetext{
4 The prosaic and poetic selves under discussion map to a variety of ways in which the first person can be invoked in Persian literary speech. The commonest forms are the words man (I) and $m \bar{a}$ ('we' used to indicate a singular), but authors can refer to themselves through a wide variety of euphemisms such as 'the writer' (navisandeh), 'this wretch' (in haqiir), and so on. For current purposes, I am limiting myself to the strong binary contrast between prosaic and poetic selves, without getting into the intricacies of why certain forms are used to invoke one or the other in particular discursive circumstances.
} 
The poetic self is individualistic through emphatic self-assertion rather than by appreciation from the outside. It is marked by a fierce independence that often requires rejection of norms. The individualistic side of the poetic self is also emotional, even sentimental; it is a vehicle for the expression of feelings that are seen to convey the uniqueness of its circumstances and reactions.

The poetic self's dividualism rests on its claim to universality. It is dividualistic through the presumption of an identity shared across humanity. Although poetic first person assertions describe intimacies that seem exceedingly personal on the surface, it is a mistake to take these on face value as simple expressions of the circumstances of the poet who composed the verses. All substantiations of the poetic 'I' are posture-driven products. Poetic virtuosity consists of innovative uses of generic language that turn well-worn tropes into new and evocative expressions. The first-person voice we encounter in poetic speech indexes a universality that the discourse presumes as being present in all humans in varying capacities. Somewhat paradoxically, the poetic 'I' projects intimacy while being emphatically impersonal in that it is bound to a genre that does not allow for a free relationship between voice and person. The poetic ' $\mathrm{I}$ ' is thus a dividual part that is understood to go into the making of the complex human person. When it comes to the poetic self, both the individualistic and dividualistic elements are focused on internal states of the human person. The social sphere is certainly implied but does not drive the formation of the self as in the case of the prosaic self. With these conceptual formulations in mind, let us now see how the issues play out in the details of Balyānī's work.

\section{The prosaic self}

The preface to Balyānī's work contains an extended autobiographical narrative that, he says, he is providing because it contains circumstances 'not devoid of peculiarity' (Balyānī 2010, 1:16). He traces his paternal genealogy to a famous Sufi master separated from him by seven generations. His parents got married in Isfahan, Iran, and his father left for India soon after Balyānī was conceived, where he died before his son's birth on 3 Muharram 973 AH (31 July 1565 CE). Weaning from his mother suddenly at the age of one, Balyānī claims that, from that point to the age of fifty, he could remember almost everything that had passed in front of his senses 'like etchings on stone'. This seemingly eidetic memory helped him to excel during a traditional education in the religious and philosophical sciences. He had an aptitude for poetry as well, although his mother and other guardians dissuaded him from it, considering it frivolous in comparison with the religious 
sciences that he was expected to master thoroughly on account of his genealogical heritage and evident talent. He says that he acquiesced to this restriction only until the age of twelve, when his mother passed away as well, leaving him completely orphaned (Balyānī 2010, 1:18-20).

Between the ages of twelve and twenty, he spent time in Isfahan, Yazd, and Shiraz, becoming ever more adept at many kinds of learning. His inward concentration on the development of his connection to God led him to experience a vision of the Prophet Muhammad, a customary marker of divine favour in this socioreligious context. At twenty years old, he became attached to the blind Safavid king Muhammad Khudābandeh (d. 1595-96), from there on becoming a part of courtly life in Iran, principally due to his extraordinary facility with Persian poetry. The apogee of his career in this regard was an incident that occurred in Isfahan in 1598 CE. The reigning king Shāh 'Abbās (d. 1629) had just come back to Iran from Central Asia after defeating his Uzbek rivals and had decided to make Isfahan the empire's new capital. To commemorate the event, the city's monuments were lit up with lamps at night. In a carnivalesque atmosphere, a competition was held for the best quatrain describing the city's illuminated condition. Judged by the king himself, Balyānī claims that his following verses won the competition that evening:

Isfahan's square, shining like the moon and the Pleiades, casts a hundred marks on the chest of the highest celestial sphere.

This is no illumination! Rather, spread in front of the king, are stars fallen from the sky in poses of prostration.

(Balyānī 2010, 1:29)

After a few years with the court, Balyānī parted company from the Safavid establishment and spent some years traveling, with stays in Yazd, Isfahan, Qazvin, and Shiraz, in Iran, and Shi'i holy shrines in southern Iraq. He then decided to undertake a journey to India in 1606. While on the way, he heard the news of the death of the Mughal king Akbar (d. 1605) and upon arrival in Lahore, he stayed for a year and a half as a part of the court of the new Mughal king Jahāngīr (d. 1627). He then moved to Agra together with the court, the same association also leading him to travel to Gujarat, where he spent three years, followed by a return to Agra in 1611-12, when he could not arrange for a passage to Arabia via sea to perform the hajj. He states that he was in Agra at the time of writing the introduction, working assiduously to complete his massive compendium of Persian poets in the years 1613-15 (Balyānī 2010, 1:30-32).

In addition to the narrative in the preface to the work, Balyānī's autobiographical voice - the prosaic self - permeates the fabric of his narrative in the form of indicating his first-hand knowledge of poets contemporary to him. Some prominent examples, picked from various bins in the alphabetical organization, 
are: Bībī Turān Shāh, a princess known for her intellect and poetic talent (Balyānī 2010, 2:926); Jismī Hamadānī, whom he describes as a person from Hamadan who had arrived in India in the antinomian garb of a Qalandar and was now resident in the Deccan (2:1046-53); Rāy Manōhar, a Hindu prince who had been taken into the Mughal court and was regarded as an accomplished poet in Persian (3:1587-93); Sharaf al-Dīn Ḥasan Shafāyī Iṣfahānī, who was fifty-seven years of age in 1613 and had been known to the author most of his adult life (4:2239-52); Fikrī Khurāsānī, a specialist in quatrains, who cultivated a bizarre outward appearance while being a part of the court of Akbar (5:3312-19); Qulī Khān Bēg Mujrim, an Iranian nobleman, both a poet and a musician, who had travelled to India with Balyānī (6:3467-73); Muhammad Ḥusayn Naẓīī, an Iranian emigre who had done very well in India as a Mughal official and had died in Gujarat (7:4439-69); Shaykh 'Alī Naqī Kamra-yī, whom Balyānī had known as a close companion in Iran, hearing the news of his death after arrival in India (7:4476-93); Qāżì Nūrī, whom his teacher had nicknamed 'jackass' despite his skill in composing poetry (7:4504-17); Mīr Vālahī Qumī, known equally as a musician and a poet (7:4558-72); and Vaḥshī Bāfaqì, a poet regarded as a legend in his lifetime due to the freshness of his composition (7:4581-95). Needless to say, this list can be extended to hundreds of names.

When Balyānī speaks in the first person in prose, his voice substantiates the entity I have called the narrative's prosaic self. Throughout its instantiation in both autobiographical and prosopographical forms - the prosaic self is given external framing. This includes reference to dates in the Hijri calendar, through which his life is pegged to an impartial temporal scale. Then there are the references to normative authoritative structures such as his kin, other poets and scholars, and kings of the Safavid and Mughal dynasties. These elements represent diachronic structures of authority that feed into his self-presentation, whether directly or through implication.

The work's prosaic self can be read as being both individualistic and dividualistic, as I indicated in the conceptual summary above. On the individualistic side, Balyānī clearly portrays himself as special, both as a distinct person who came into being at a certain time, and as someone who possesses extraordinary capabilities that have had a hand in defining his life's trajectory. But the sense of specialness rests, ultimately, on his self-inscription into structures of authority that define his social setting. His prosaic self depends on being incorporated into matters such as genealogies, political structures such as empires, and social hierarchies to which he subscribes and aspires. The prosaic self is constructed in the middle between the individualistic and dividualistic aspects of his being. In his self-description in prose, he is both an exceptional person and someone whose significance is based on being ensconced within the sociopolitical reality that surrounds him. 


\section{The poetic self}

The distinction between the prosaic and poetic selves that I have drawn is affirmed explicitly in Balyānī's own presentation: his catalogue of poets includes an entry on himself. His pen name was Taqì, placing him under the letter ' $t$ ' in the scheme of his work, in the enclosure meant for the most recent poets. His description of himself in this entry references the autobiographical narrative at the beginning of the work but provides little extra detail that would allow us to substantiate him as being situated within specific temporal and social structures. Self-described as a poet, he appears quite different from the prosaic self. He treats himself as he would all other poets whom he has decided to include in his work on account of their poetic compositions. He enumerates the amounts and types of poetry he has composed over his lifetime, describing also what has been lost and what remains with him. As in the case of all the other entries on poets, much of his entry on himself consists of samples of poetry. I will provide translations of three examples that can give a sense for the range of his poetic expression. For present purposes, I suggest that we regard Taqī (i.e. Balyānī) as an example for the overall paradigm of the poetic self we encounter in his work.

The following couplet is an example of the expression of a highly personal sentiment:

Moonfaced one, the day I saw your silvery form, of a morning, naked in the hammam,

by the evening, as stars made their appearance,

from desire for you, my spirit had melted, oozing out from my pores.

(Balyānī 2010, 2:925)

In this example, the focus is squarely on the relationship between the body and emotions. The verses manage to interweave the heat of the hammam and of the passion, placed in a day and night cycle that withers body and spirit. The verses' effect is created through poetic/conceptual alliteration between the revealing of the beloved's form by the removal of clothes, the rising of desire from within the self, the shining forth of the stars with the coming of darkness, the pouring of sweat from the skin pores, and the gliding of the spirit out of the body.

In contrast, the following verses also locate the self in the body but now with the aim of emphasising the self's separation from presumed normative conduct:

'Farewell, heart, as I fasten pilgrim's garb, headed for the beloved's sanctuary. I tie up the provisions, determined to travel to the Ka'ba of hopefulness. 
God, make me steadfast in being an unbeliever!

Like someone non-Muslim by birth, I tie the knot of the zunnār belt' (Balyānī 2010, 2:913). ${ }^{5}$

In this instance, the poetic self acquires its distinctiveness through being devoted to the beloved. Opposite to the melting of the spirit in the first case, here outward distinction, manifested in the form of non-Muslim clothing, provides evidence for the self's radical transformation through the way love has affected it. The tie created by the fact of falling in love reverberates to clothes, provisions, and socioreligious bonds in the verses' imagery.

The last sample I provide is a full ghazal (a short poem in rhyming couplets), a lengthier text that exemplifies a cascading series of complex topoi that are a part of the poetic self encountered in Balyānī's work:

'I am the one who, like heart, is the king of the celestial throne.

Like intellect, I am ruler over the clime of perfections. [1]

My mind is the tavern of the hidden world.

My intellect is the manifesting place of sanctity's witness. [2]

My speech is sister to the beloved's ruby lips.

I am fellow resident in the abode that is the patience of lovers' hearts. [3]

Like the evening of separation, there is no deliverance from my sorrow.

Like the day of affliction, I am not an aid that saves from oppression. [4]

I am the flute's exile: what, after all, grieves me in life?

I am the flute's mourning: what tragedy, after all, has afflicted me? [5]

In companions' sight, I am a precious stone lit up in fire.

In the enemy's eye, I am a diamond needle piercing through silk. [6]

A knight and two rooks make moves, play the game.

In the arena of grasping speech, I am glory and dispel oppression. [7]

Like Anvarī of the age, I do not have pearls of speech.

When speechlessness is divine favour, I am Zahīr. [8]' (Balyānī 2010, 2:916f.).

On its surface, this poem reflects an absolute focus on the speaker, the poetic self, the first-person pronoun being present in every couplet. It lays out distinctions accorded to the self in a boastful way, also showing this self to be an immensely capacious entity. However, the poem's grander implications come to light once we see it as a densely intertextual paean to the traditions of Persian poetry, referencing thematic

5 Much utilized in poetry to signify concurrent unbelief and faithfulness, the zunnār was a coloured belt required to be worn by non-Muslim men in public in certain early Muslim societies. 
resonances and directly invoking famous predecessors. Although a full explanation of the contents of this poem would require too much space in the context of the present discussion, I will provide a summary mapping between the text and the larger tradition for us to appreciate its various associations.

The poem can be divided into four parts. Following the numbers I have assigned to verses, these are: (i) 1 and 2 are references to cosmology; (ii) 3 through 5 are plays on the presumed world inhabited by the lover, the chief stock character in Persian poetry; (iii) 6 and 7 contain hyperboles concerned with the poet's presumed role in social and courtly settings; and (iv) 8 refers to two earlier poets, providing us a way to identify the location of the poem's usage. The first two verses are a play on the interconnection between the macrocosm and the microcosm. In the first, 'heart' and 'throne' are references to the doctrine that the place of the heart within the human being is the same as that of the celestial throne, mentioned in the Quran, in the cosmos. This identification was the basis for complex theories in which the human journey into the innermost part of one's being was also seen as a climb up the cosmic ladder to be in the proximity of God. Such journeys were imagined to take place through cultivating one's intellect as well as the capacity for becoming the subject of divine self-manifestation. The point of the second verse is to claim that the speaker's mind has become such a place of manifestation and that he has attained the intellectual maturity to become a witness to the divine in the deep sense.

Verses 3 through 5 relate to the presumed game of love, in which the poet takes on the role of lover, and God or another human being can be the beloved. The first hemistich of the third verse refers to the expectation that speech of love, i.e. poetry, comes into being through unrequited love. The poet/lover pines for the beloved, who either shuns or remains coy. But speech produced in this way holds such charm that even the non-acquiescent beloved cannot but let it flow on the lips. The second hemistich of the third verse invokes a different part of the love tale: here the poet takes on the expected role of suffering patiently while the beloved remains unattainable. The fourth verse hinges on the 'evening of separation' and 'day of affliction', stock scenarios against which lovers' patience is tested. Here the poet takes on the characteristics of experiences associated with these durations. The fifth verse continues with the theme of grief and mourning, this time by reference to the mournful sound of the reed flute. The flute's voice is a direct reference to one of the most famous poems in Persian literature: the Maśnavī of Jalāl al-Dīn Rūmī (d. 1273) that begins by comparing the flute's voice to the cry of the human soul searching for the divine (Papan-Matin 2003).

The poet as a stock character is expected to possess tremendous mental alacrity that allows him to use his power over language to acquire social mastery. The traditional proving ground for this to happen is the royal court, presumed to be split into warring factions vying for resources and the sovereign's favour. The sixth 
verse refers to this situation, indicating the poet's great value to his friends and his deadliness when in the role of a conniving enemy. The first hemistich of the seventh verse continues this scheme, transferring it to action on the chessboard, a courtly game. The second hemistich then identifies the game in play as that of understanding and producing speech, the domain in which the poet claims excellence. Finally, the last verse refers to Awḥad al-Dīn Anvarī (d. c. 1150-80) (Anvarī 1961) and Zahīr al-Dīn Fāryābī (d. 1201) (Fāryābī 2003), early Persian poets regarded as masters of composing panegyrics for kings and other elite patrons. The citation of these two as the poet's predecessors makes it nearly certain that Balyānī's own poem was written for use in the setting of the Safavid or Mughal courts.

My explanations of the Persian verses in English do the original no favours, even as they may make the matter more understandable to readers unfamiliar with the allusions. It seems counterproductive and tawdry to disassemble the poem's carefully constructed affect into humdrum rationalisations. But there is an important lesson in the contrast in that it provides a sense for what Balyānī is after in his evaluations of poetic production in Persian. As in other poetic forms, the verses are spectacularly economical deployments of language in the service of conveying ideas, emotions, interpersonal relationships, and so forth. The examples I have provided from Balyānī's entry on himself aim to substantiate a part of the concrete content associated with the poetic self as it comes across in his work. Multiply this by thousands and we have a sense for the experience of reading the work at length.

As I hope is clear by now, the poetic self is highly invested in individualistic self-evocation that can very easily extend to posing radical challenges to ideological and societal norms. Balyānī's verses describe him as lusting after a naked person he has seen in the baths, and he openly professes repudiation of Islam and taking up the garb of non-Muslims while pursuing a beloved. However, as evident in the last example, these and other invocations of individualism index longstanding traditions. The poetic self is a voice shared among all the poets Balyāni is keen to showcase in his monumental work. The 'person' who speaks in this voice is present in all human beings, although it never encompasses the full humanity of a particular individual. The poetic self is then dividualistic in the same measure as the seeming individuality registered in its strident statements in verse.

\section{Conclusion}

I hope to have shown that the debate regarding in/dividuality provides us analytical tools to undertake assessments of complex literary products. This deployment of the distinction is heuristic rather than descriptive, its value residing in 
the degree to which it helps us to comprehend texts in context. When we encounter a work such as the one I have explored, we are presented with the challenge of imagining the social world that gave rise to it but is no longer available for direct observation. Balyānī's work is, on the surface, replete with references to the first person. If we take all 'I's and its equivalents present on face value, the work is rendered utterly contradictory and incoherent. For example, the authorial self affirms religious norms while also stridently flaunting them. It is self-effacing, yet also boastful and invested in seeing itself as the exception. It delights in claiming novelty of thought and expression while also proving bound to received tradition in the utmost. In this situation, the distinction between individualistic and dividualistic aspects allows us to generate a conceptual basis for resolving the contradictions, thereby making the work a window onto the social world of its origins.

In the approach I have taken, it is crucial that the contents of the terms individualism and dividualism are not taken as standard based on data coming from any given society or textual base. That is, no particular characteristics should be allowed to be seen as inherent in what we understand by the two terms. Rather, the contents of the terms must be derived from a careful analysis of the data at hand. In the case of Balyānī, I hope to have shown that we have a single work that has two types of selves, each with its own distinctive forms of individuality and dividuality. Individuality and dividuality are relative rather than absolute descriptors. The two cannot be taken as universal substantives, and their associations need to be constituted from the specific examples we are exploring. Any meanings we can assign to them must be recovered from the specifics of the data we are confronting rather than through a priori presumptions.

My perspective on individuality and dividuality cashes out in the way it allows me to think productively about the societies that were the origins of the literature that I seek to interpret. By thinking about the question as I have done, I can understand Balyānī as both a being rooted in his world and as someone who acted upon the world as an individual, projecting himself as different from others who surrounded him in various circumstances. This is an important and non-trivial analytical benefit that derives from the discussion of in/dividuality. Reading genre-bound literature produced in societies to which we have no direct access is a challenging matter. We are mistaken to read this material simply as a reflection of a formalised world, in which human actors were nothing but automatons carrying out societal scripts dictated to the last rule. But it is equally problematic to take on face value assertions of selves we find in these works, in the form of the use of first-person pronouns and otherwise. We cannot regard the words that meet our eyes as literal self-ascriptions of the people who produced the works. The in/dividuality paradigm provides a systematic and systemising approach to explore literature that is simultaneously virtuosic and a product of 
tradition. It allows us to imagine our subjects as complex beings existing between the poles of interiority and exteriority.

\section{References}

Āl-i Dāvūd, Sayyid 'Alī. 1996. “'Arafāt al- 'āshiqīn: Sayrī dar aḥvāl va āṣār-i mu'allif-i ān', Nāma-yi farhangistān 1(3). 33-53.

Āl-i Dāvūd, Sayyid 'Alī. 2008. 'Shā'irān-i zan dar 'Arafāt al-'āshiqīn', Nāma-yi farhangistān 9(4). 79-94.

Anvarī, Awḥad al-Dīn. 1961. Dĩvān-i Anvarī. Ed. Muḥammad Taqī Mudarris Rażavī. Tehran: Bungāh-i Tarjuma va Nashr-i Kitāb.

Balyānī, Taqī al-Dīn Awḥadī. 1985. Surmah-yi Sulaymānī. Ed. Maḥmūd Mudabbirī. Tehran: Markaz-i Nashr-i Danishgāhī.

Balyānī, Taqī al-Dīn Awḥadī. 2010. 'Arafāt al- 'āshiqīn va 'araṣāt al- 'ārifīn. Eds. Zabīḥallāh Șāḥibkārī, Āmina Fakhr Aḥmad, Muḥammad Qahramān. 8 volumes. Tehran: Mīrāṣ-i Maktūb.

Fāryābī, Ẓahīr al-Dīn. 2003. Dīvān-i Ẓahīr al-Dīn Fāryābī. Eds. Amīr Ḥasan Yazdgardī, Aṣghar Dādbeh. Tehran: Nashr-i Qațreh.

Gulchīn Ma'ānī, Aḥmad. 1985. Tārīkh-i Tažkirahā-yi Fārsī. 2 volumes. Second Printing. Tehran: Intishārāt-i Kitābkhāna-yi Sanā'ī.

Losensky, Paul. 1998. Welcoming Fighānī: Imitation and poetic individuality in the Safavid-Mughal ghazal. Costa Mesa, California: Mazda Publications.

Papan-Matin, Firoozeh. 2003. 'The crisis of identity in Rumi's "Tale of the reed”', Comparative Studies of South Asia, Africa and the Middle East 23(1-2). 246-53.

Smith, Karl. 2012. 'From dividual and individual selves to porous subject', Australian Journal of Anthropology 23. 50-64.

Valāyatī, 'Alī Akbar. 2013. Taqĩ al-Dīn Awhadī Balyānī. Tehran: Shirkat-i Sahāmī-yi Kitābhā-yi Jībī. 